\title{
Olhares sobre Alexandre Koyré, historiador e filósofo do pensamento científico
}

\section{Perspectives on Alexandre Koyré, historian and philosopher of scientific thought}

\author{
Hallhane Machado \\ Doutoranda em história, Universidade Federal de Goiás. \\ hallhane@gmail.com
}

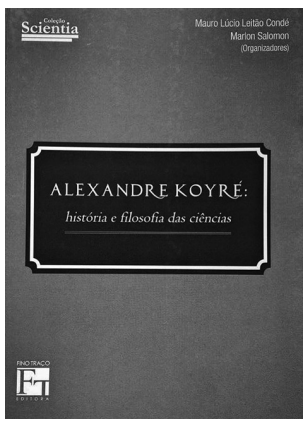

SALOMON, Marlon; CONDÉ, Mauro Lúcio Leitão (Org.). Alexandre Koyré: história e filosofia das ciências. Belo Horizonte: Fino Traço. 2015. 292p. $\curvearrowright 1$ uando as vicissitudes do tempo permitem uma vida relativamente longa de um autor singular e enérgico, quando o devir não é absolutamente adverso à sua obra e nela o interesse não se perde, as datas comemorativas se tornam uma conveniente ocasião para revisitála. Em 2014, completaram-se 50 anos desde que Alexandre Koyré cessou de trabalhar e também de viver. Foi aproveitando o momento para discutir não o término, mas a vitalidade de um pensamento peculiar, que foram realizados dois eventos, naquele mesmo ano, o terceiro Colóquio de História e Filosofia da Ciência [Alexandre Koyré], na Universidade Federal de Minas Gerais (UFMG), e o Colóquio Koyré, na Universidade Federal de Goiás (UFG). Como fruto desse esforço, eis que, um ano depois, apresenta-se a nós o livro organizado por Marlon Salomon e Mauro Lúcio Leitão Condé.

Embora seja certo que a obra de Koyré não se resume à reflexão acerca do pensamento científico e sua história, alerta ali frequentemente dado ao leitor, a coletânea de textos sobre o autor francês de origem russa assenta-se principalmente sobre o domínio pelo qual ele se tornou leitura obrigatória. Ela reúne trabalhos a respeito de diferentes elementos da obra koyreana referente à história do pensamento científico, trabalhos pelos quais é possível ver a complexidade e profundidade de sua perspectiva e, assim, a pertinência de estudos que a tomem como objeto.

No entanto, antes das análises historiográficas, no primeiro capítulo do livro, o leitor tem o privilégio de se deparar com uma tradução de "Copérnico," texto do próprio Koyré, publicado em 1934. O lugar ocupado na coletânea, de fato, é bastante apropriado. O texto em questão marca o início dos estudos de Alexandre Koyré voltados preferencialmente para a história do pensamento científico. Nele já se torna possível entrever traços característicos do autor em questão, alguns dos quais são abordados nos capítulos posteriores, como a exigência teórica e metodológica de analisar as teorias científicas do passado à luz de sua própria estrutura conceitual, a concepção da unidade do pensamento humano ${ }^{1}$ e o período a que, a partir da 
década de 1930, direcionou seus estudos majoritariamente: os séculos XVI e XVII, momento da "revolução científica" iniciada por Copérnico. ${ }^{2}$

Apesar de os dez capítulos que se seguem não contemplarem um mesmo ponto de vista e aspecto dos trabalhos koyreanos, o que dificulta uma apresentação acurada, poderíamos separá-los em quatro grupos.

O primeiro grupo de autores oferece ao leitor uma análise direcionada especificamente ao trabalho de Alexandre Koyré, destacando seus traços de novidade essencial, apontando preceitos e implicações. Marlon Salomon analisa a novidade teórica e metodológica de sua concepção de história, sublinhada por muitos autores, embora pouco aprofundada. Por meio da precisão das ideias de "presente" e "atualidade" em Koyré, e seus papéis no trabalho desse autor, é possível entender a importância e originalidade atribuída por Pietro Redondi ao método historiográfico koyreano. Gérard Jorland completa a análise dos traços marcantes daquele autor, discorrendo sobre o conceito de "revolução científica" e a empatia fenomenológica. Ao leitor é exposta a tese do livro que se tornou referência indispensável nos estudos sobre Koyré. ${ }^{3}$

O segundo grupo discorre sobre certas propostas e conceitos atribuídos a Koyré, tendo em vista sua aplicação em seu próprio trabalho. Verônica Calazans retoma a supracitada metodologia historiográfica, analisando-a em sua interpretação acerca das relações entre as teorias de Newton e Descartes. Patrícia Kauark-Leite discorre sobre a postura filosófica de Koyré, entre os conceitos clássicos de "realismo" e "historicismo", asseverando sua admissão ao que poderíamos denominar "realismo historicista", à maneira de Bas van Fraassen.

O terceiro grupo oferece ao leitor a oportunidade de se inteirar sobre as interpretações recorrentes da obra koyreana, ao mesmo tempo que também chama a atenção para as classificações superficiais e os reducionismos. Francismary Silva, Eduardo Barra e Luiz Abrahão constroem suas análises a partir do que foi admitido como o legado koyreano, revisitando a célebre etiqueta de "internalista", ${ }^{4}$ posta em Alexandre Koyré, e a tese da "dívida intelectual" de Thomas Kuhn e Paul Feyerabend, em relação a noções e posturas do historiador e filósofo francês.

O quarto grupo apresenta interessantes análises dos trabalhos de Koyré ao lado de alguns de seus contemporâneos como Hélène Metzger, Gaston Bachelard e Ludwig Wittgenstein. Ronei Mocellin expõe a possibilidade de um diálogo conceitual entre Metzger e Koyré, demonstrando semelhanças - como seus métodos historiográficos, a dedicação de ambos a uma história do pensamento - e também diferenças - como o modo de conceber a ideia de unidade do pensamento. Fábio Almeida, embora não deixando de frisar a individualidade dos autores, situa Bachelard e Koyré em um mesmo espaço, aquele inaugurado pela filosofia de Husserl na episteme moderna. A entrada da fenomenologia husserliana na França da década de 1930 significou a "entrada da ideia na história", que, na hipótese de Almeida, "está na origem dos trabalhos de Bachelard, Koyré e outros" (p.194). Por fim, Mauro Lúcio Leitão Condé empreende uma análise de Koyré ao lado de um autor inusitado. Condé apresenta a possiblidade de reconsiderar o internalismo de Koyré a partir do segundo Wittgenstein, "superando os seus aspectos negativos e o requalificando para que ele possa ser entendido como a afirmação da autonomia da ciência e não o isolamento entre ciência e sociedade" (p.240). 
Por vezes, ao término das muitas resenhas que elaborou, Koyré destacava a fragilidade de um empreendimento que propõe apresentar uma obra multifacetada sem dispensar o caráter da brevidade. De fato, ele tinha razão. Expor o resumo do conteúdo de Alexandre Koyré: história e filosofia das ciências não foi nossa pretensão, mas oferecer uma pequena amostra desse livro que, entre os escassos trabalhos publicados aqui no Brasil, aborda um autor cuja importância - reconhecida por Michel Foucault, Raymond Aron, Marshall Clagett, Georges Canguilhem, Thomas Kuhn e tantos outros - não se pode prescindir de reafirmar.

\section{NOTAS}

${ }^{1}$ Para Koyré, as "formas mais elevadas" do pensamento humano - filosofia, ciência e teologia - se entrecruzam. Não se pode separá-las "em compartimentos estanques" (Koyré, 1973, p.12). Copérnico, Kepler, Galileu e Descartes, por exemplo, não lidavam com questões apenas científicas, mas metafísicas e religiosas.

2 Para Koyré, a dita "revolução" foi preparada por um "longo e penoso trabalho do espírito" (Koyré, 1992, p.203), ou seja, não foi feita de uma só vez.

${ }^{3}$ Referimo-nos ao livro La science dans la philosophie, publicado em 1981.

${ }^{4}$ Trata-se da concepção, sintetizada por Condé, "de que a ciência encontra suas justificativas nela mesma, independente de influências de contextos sociais" (p.238).

\section{REFERÊNCIAS}

KOYRÉ, Alexandre.

Estudos galilaicos. Trad. Nuno Ferreira da Fonseca. Lisboa: Publicações Dom Quixote. 1992.
KOYRÉ, Alexandre.

Orientation et projets de recherches. In:

Koiré, Alexandre. Études d'histoire de la pensée scientifique. Paris: Gallimard. 1973. 